\title{
Divergent Regulation of the Glut 1 and Glut 4 Glucose Transporters in Isolated Adipocytes from Zucker Rats
}

Oluf Pedersen, ${ }^{\star *}$ C. Ronald Kahn, ${ }^{*}$ and Barbara B. Kahn

${ }^{*}$ Research Laboratory, The Joslin Diabetes Center and The Department of Medicine, Brigham and Women's Hospital; "Steno Diabetes Center, Copenhagen, Denmark; and ${ }^{\S}$ The Charles A. Dana Research Institute and Harvard Thorndike Laboratory of Beth Israel Hospital and Department of Medicine, Beth Israel Hospital, Harvard Medical School, Boston, Massachusetts 02215

\begin{abstract}
We have studied the relationship between glucose uptake rate and Glut 1 and Glut 4 protein and mRNA levels per fat cell in lean (FA/FA) and obese (fa/fa) Zucker rats at 5, 10, and 20 wk of age, and after induction of acute diabetes with streptozotocin. 5 wk obese rats exhibit insulin hyperresponsive glucose uptake, whereas 20 wk obese rats show insulin resistant glucose uptake. The relative abundance of Glut 1 and Glut $4 \mathrm{mRNA}$ and protein per equal amount of total RNA and total membrane protein, respectively, is lower in adipocytes from obese rats. However, at all ages the enlargement of fat cells from obese rats is accompanied by a severalfold increase in total RNA and total membrane protein per cell. Thus, on a cellular basis, mRNA and protein levels of Glut 4 increases in young obese rats and gradually declines as a function of age. Basal glucose uptake is increased severalfold in fat cells from obese rats, and in parallel Glut 1 expression per cell in obese rats is two- to threefold increased over lean rats at all ages. Acute diabetes in 20 wk obese rats causes a profound downregulation of glucose uptake and a concomitant reduction of both Glut 1 and Glut 4 protein levels. Thus, changes in Glut 4 expression are a major cause of alteration in insulin-stimulated glucose uptake of adipocytes during evolution of obesity and diabetes in Zucker rats. (J. Clin. Invest. 1992. 89:1964-1973.) Key words: aging • obesity $\bullet$ diabetes $\bullet$ insulin resistance $\bullet$ lipogenesis
\end{abstract}

\section{Introduction}

The obesity of the fa/fa Zucker rat is due to a single recessive autosomal gene mutation, as yet unidentified (1). Excessive adiposity is evident in fa/fa Zucker rat as early as 2 wk of age ( 1 , 2 ), and this expansion of the fat depot continues until about 15 wk (3-7). This obesity is like human obesity accompanied by hyperinsulinemia and hyperlipidemia but normal blood glucose levels (1-7). The initiating lesion leading to obesity in the Zucker rat is unknown, but at least two hypotheses have been considered (8-10). In one, hyperinsulinemia of pancreatic or neuroendocrine origin is thought to be primary with secondary increases in metabolic activity of adipose tissue. Alternatively, there may be an inborn error of metabolism in adipose tissue

Address correspondence to Dr. Oluf Pedersen, Steno Diabetes Center, Niels Steensens Vej 2, 2820 Gentofte, Copenhagen, Denmark.

Received for publication 19 February 1991 and in revised form 17 January 1992.

J. Clin. Invest.

(c) The American Society for Clinical Investigation, Inc.

$0021-9738 / 92 / 06 / 1964 / 10 \quad \$ 2.00$

Volume 89, June 1992, 1964-1973 with an early hyperfunction of glucose uptake and lipogenesis, followed by insulin resistance and hyperinsulinemia. No matter which of the two pathogenetic models is the most relevant, it is clear that both basal and insulin-stimulated glucose uptake are enhanced in adipocytes from young fa/fa Zucker rats $(4,5)$. Studies of inguinal adipocytes from 1 mo old fa/fa rats have also shown an increased glucose transport activity with a fourto fivefold increase in the number of glucose transporters measured by cytochalasin B binding (11).

Facilitated glucose transport is mediated by several genetically distinct glucose transporters. Glut 1 appears ubiquitously expressed in mammalian tissues, but predominantly in insulininsensitive tissues such as erythrocytes, brain, and placenta; Glut 2 is most highly expressed in kidney, pancreatic islets, and splanchnic tissues; Glut 3 is present in almost all tissues of the rat except adult skeletal muscle; Glut 4 is considered the likely "insulin responsive" transporter since it is expressed in skeletal and heart muscle and adipose tissue; and Glut 5 is expressed primarily in small intestine (12). Although both Glut 1 and Glut 4 are present in adipose cells (13-17), Glut 1 is much less abundant than Glut 4 (18). Moreover, the concentration of Glut 1 protein increases only about twofold in the plasma membrane of rat adipocytes in response to insulin, whereas the concentration of Glut 4 protein increases about 10 -fold in adipocyte plasma membranes upon insulin stimulation $(19,20)$. Finally, several groups of investigators have recently reported that in fat cells from normal lean rats made acutely diabetic by streptozotocin injection, there is a substantial decrease in Glut 4 mRNA and protein which is reversed by insulin treatment, whereas Glut 1 is unaltered by diabetes (20-23).

Hence, the present investigation was designed to answer three questions: (a) What is the expression of Glut 1 and 4 at the gene and protein level in adipocytes from genetically obese Zucker rats? $(b)$ Is the expression of glucose transporter genes changed during the evolution of obesity? $(c)$ Finally, what is the effect of acute streptozotocin diabetes on adipocyte glucose transporters in aged, obese, and insulin resistant fa/fa Zucker rats?

\section{Methods}

Animals and experimental design. Male Zucker rats were bred in the animal facilities of Vassar College, New York. Lean homozygous (FA/ $\mathrm{FA})$ and obese $(\mathrm{fa} / \mathrm{fa})$ rats were received from the supplier at least $1 \mathrm{wk}$ before killing at the age of 5,10 , and $20 \mathrm{wk}$. In half of the obese 20 -wkold rats, streptozotocin at a concentration of $40 \mathrm{mg} / \mathrm{kg}$ body wt (dissolved in $10 \mathrm{mM}$ sodium citrate, $\mathrm{pH} 4.5$ ) was injected into the tail vein $36 \mathrm{~h}$ before death to produce acute diabetes. The animals were maintained with ad lib. feeding of standard rat chow and killed by $\mathrm{CO}_{2}$ inhalation and decapitation in the fed state between 8 and 10 a.m. The experimental protocol was approved by the local animal ethics committee. 
Chemicals. $\left[{ }^{32} \mathrm{P}\right] \mathrm{UTP}(800 \mathrm{Ci} / \mathrm{mmol}),\left[{ }^{32} \mathrm{P}\right] \mathrm{dCTP}(3,000 \mathrm{Ci} / \mathrm{mmol})$, and $\mathrm{D}\left[{ }^{14} \mathrm{C}\right]-\mathrm{U}$-glucose $(305 \mathrm{mCi} / \mathrm{mol})$ were supplied by New England Nuclear (Boston, MA). Crude collagenase was from Cooper Biomedical Inc. (Malvern, PA). Bovine serum albumin (Fraction V) was from Reheis Chemical Co. (Kankakee, IL). T7 RNA polymerase was obtained from Stratagene Inc. (San Diego, CA). Agarose was from BRL (Bethesda, MD), and guanidium isothiocyanate was from Fluka Chem. Corp. (Ronkonkoma, NY). All other chemicals were purchased from Sigma Chemical Co. (St. Louis, MO).

Preparation of adipocytes and measurement of fat cell size. Immediately after the rats were killed, the epididymal fat pads were removed and fat cells were isolated by the method of Rodbell (24), and modified by Pedersen et al. (25), using crude collagenase at a final concentration of $0.5 \mathrm{mg} / \mathrm{ml}$. All incubations were carried out in Krebs-Ringer-bicarbonate buffer reduced to $10 \mathrm{mM} \mathrm{HCO}_{3}$ and supplemented with $30 \mathrm{mM}$ Hepes, $\mathrm{pH} 7.4$, at $37^{\circ}$ containing $1 \%$ bovine serum albumin. The collagenase-isolated adipose cells were washed three times in albumin-free TES $^{1}$ buffer ( $20 \mathrm{mM}$ Tris-HCl, $1 \mathrm{mM}$ EDTA, $255 \mathrm{mM}$ sucrose, $\mathrm{pH}$ 7.4). No centrifugation was used in the washing procedure, but between washes the fat cells were allowed to float. Just before homogenization, aliquots were taken for measurement of cell size and number. The diameters of at least 200 adipocytes were measured for every cell sample in a cell-counting chamber, as described previously (25). The coeffcient of variation was 0.03 . From the adipocyte diameter (D), the adipocyte volume $\left(\pi \mathrm{D}^{3} / 6\right)$ was calculated. The concentration of cells in adipose cell suspensions was calculated as the adipocyte volume fraction (measured in a hematocrit capillary tube) divided by the mean adipocyte volume. This measurement had a coefficient of variation of 0.02 at routine volume fractions of 0.40 . The mean fat cell volume, which was used for calculation of cell number concentration, was obtained from the individually computer-calculated cell volumes. Finally, the fat cell suspension was diluted in buffer to give a volume fraction of 0.01 . Microscopic inspection showed that the adipose cell preparation was homogenous without contaminations with fibroblasts or blood cells.

Glucose uptake in fat cells. In preliminary experiments using the 3-O-methylglucose transport assay and the oil centrifugation technique to separate fat cells from the radioactivity in the medium (26), we found that about $30 \%$ and $20 \%$ of the adipocytes in cell suspensions prepared from 20-and 10-wk-old obese Zucker rats, respectively, were lost by centrifugation through silicone oil (25). Attempts to solve the problem by examining the efficiency of several oils (different viscosity and relative density) at more temperatures were unsuccessful. Thus, centrifugation-induced cell loss also prevented us from using an assay that measures total cell-associated radioactivity (sum of lipophilic and hydrophilic products) $(27,28)$. Therefore, glucose uptake was estimated in fat cells by measuring the conversion rate of uniformly labeled $\left[{ }^{14} \mathrm{C}\right]$-D-glucose to total lipids at trace concentration $(1.5 \mu \mathrm{M})$ (27). In samples of separate adipose cell suspensions covering a wide range of cell volumes, comparative studies of 3-O-methyl glucose transport and glucose metabolism have shown that at low trace glucose levels $(0.1-40 \mu \mathrm{M})$, glucose transport is rate limiting for both basal and maximal insulin-stimulated glucose metabolism (lipogenesis and production of hydrophilic glucose metabolites as lactate and pyruvate as well as glucose oxidation) $(27,28)$. Under such experimental conditions, about $60 \%$ of cell-associated ${ }^{14} \mathrm{C}$-radioactivity is recovered in cell lipids $(27,28)$. In other words, measurement of the major metabolic pathway in glucose metabolism of adipose cells (lipogenesis) at trace glucose concentrations is a valid tool to evaluate glucose transport activity. Isolated adipocytes in Krebs-Ringer-bicarbonate buffer $(960 \mu \mathrm{l}$ cell suspension with an adipocyte volume fraction at 0.01 , i.e., about $10^{4}$ cells $/ \mathrm{ml}$ ) were preincubated for $45 \mathrm{~min}$ at $37^{\circ} \mathrm{C}$ in polypropylene scintillation vials without or with insulin at multiple concentrations rang-

1. Abbreviations used in this paper: SSC, standard saline citrate; SSPE, sodium chloride sodium phosphate EDTA buffer; TES, $20 \mathrm{mM}$ Tris$\mathrm{HCl}, 1 \mathrm{mM}$ EDTA, $255 \mathrm{mM}$ sucrose, $\mathrm{pH}$ 7.4. ing from $10 \mathrm{pM}$ to $1 \mu \mathrm{M}(20 \mu \mathrm{l}) .20 \mu \mathrm{l}$ of $\left[{ }^{14} \mathrm{C}\right]$-D-glucose was added to the cell suspension to obtain a final trace glucose concentration of 1.5 $\mu \mathrm{M}$, and the incubation continued for another $60 \mathrm{~min}$ at $37^{\circ} \mathrm{C}$. Control experiments in fat cells from both lean and obese 20-wk-old Zucker rats showed that under these experimental conditions glucose uptake rate was linear for at least $90 \mathrm{~min}$. To circumvent interference from high concentrations of adipocyte-released compounds with known stimulatory effects on glucose transport such as adenosine, prostaglandine $\left(\mathrm{PGE}_{2}\right)$, and spermine $(29,30)$, all experiments were run in very diluted cell suspensions. Moreover, given the known fragility of large adipose cells from the old obese rats, the issue of the integrity and viability of the cells at the end of the incubation period before lipid extraction was a critical one. In three separate experiments on 20-wkold obese rats, the fat cell concentration in the medium remained unchanged during a 2-h incubation. Microscopic examination of the same cell suspensions before and after the incubation period using methylene blue and trypan blue, respectively, revealed on both occasions more than $90 \%$ cell integrity and viability and a negligible amount of fat droplets. ${ }^{14} \mathrm{C}$-labeled lipids were extracted by direct addition of $10 \mathrm{ml}$ toluene-based scintillation fluid to the incubation vial (27). After vigorous shaking, $5 \mathrm{ml}$ of the scintillation fluid was separated from the aqueous phase and transferred to another vial for counting of radioactivity. The content of labeled glucose in the toluene phase (blank values) was negligible. All glucose uptake experiments were run in triplicate.

Preparation of total membranes from adipocytes. After wash of the collagenase isolated adipose cells in albumin-free TES-buffer, cell counts were performed. The concentrated fat cell suspension was then homogenized at $17^{\circ} \mathrm{C}$, using a Potter-Elvehjem glass homogenizer. To get rid of the fat cake, the homogenate was centrifuged for $15 \mathrm{~min}$ at $16,000 \mathrm{~g}$ at $-4^{\circ} \mathrm{C}$. The pellet was resuspended in the supernatant, centrifuged for $40 \mathrm{~min}$ at $212,000 \mathrm{~g}$ at $4^{\circ} \mathrm{C}$, and again resuspended in TES-buffer. Thus, to isolate membrane proteins from adipocytes we produced a fat cake. It was necessary to discard this portion to pellet the membranes. However, the fat cake accounted to $3-5 \%$ of the volume and this proportional was the same in lean and obese cell suspensions since we made the obese cells up to a larger volume. Hence, precautions were taken to ensure that there was no differential losses in protein recovery between homogenates from lean and obese rats.

Immunoblotting. Adipose cell membranes (100 $\mu \mathrm{g} /$ lane in Glut 1 studies, and $65 \mu \mathrm{g} /$ lane in Glut 4 studies) prepared as described above were subjected to $10 \%$ SDS-polyacrylamide gel electrophoresis and electrophoretically transferred to nitrocellulose filters. Immunoreactive Glut 1 was detected using a polyclonal rabbit antiserum prepared against a synthetic peptide consisting of the 16 carboxy-terminal amino acids of the Hep G2 glucose transporter sequence (16). Glut 4 proteins were analyzed using the monoclonal antibody $1 \mathrm{~F} 8$ specific for the carboxy-terminal of Glut 4 (15). Antisera were used at $10 \mathrm{mg} / \mathrm{ml}$. Immunolabeled bands were visualized using ${ }^{125}$ I-labeled sheep anti-mouse $\mathrm{F}\left(\mathrm{ab}^{\prime}\right) 2$ fragment (Amersham International, Amersham, UK) after immunoblotting with $1 \mathrm{~F} 8$, and ${ }^{125}$ I-protein A (New England Nuclear) after immunoblotting with the polyclonal Glut 1 antiserum.

$R N A$ isolation. Immediately after collagenase isolation and cell wash, a sample was taken for cell counts and the adipocytes were resuspended in quanadinium isothiocyanate. Subsequent homogenization was performed with a Potter-Elvehjem glass homogenizer. RNA was extracted using the guanadinium isothiocyanate-CsCl method $(31,32)$. RNA was quantitated by absorbance at $260 \mathrm{~nm}$, and purity was assessed by absorbance at 280 and $260 \mathrm{~nm}$.

Differential recovery of RNA from fat cells of varying size was considered, since RNA might be trapped in the fat layer after polytroning the cells in guanadinium isothiocyanate. This layer contains a small amount of RNA but much less that comparable volume of the aqueous infranatant. Moreover, even in cells from very obese Zucker rats, the volume of the lipid phase was less than $10 \%$ of the sample volume. Hence, the total amount of RNA in the lipid layer was not significant.

Northern blot analysis. For Northern gels, total RNA $(20 \mu \mathrm{g})$ was denatured, separated by $1.2 \%$ formaldehyde agarose electrophoresis, 
and transferred to nylon membranes. The integrity of RNA and equivalent loading of RNA in each lane were assessed by visualization of the ribosomal RNA following ethidium bromide staining.

For analysis of Glut 1 RNA, the Hep G2 glucose transporter cDNA was subcloned into the BamHI site of the pGEM plasmid and the antisense RNA was synthesized using T7 polymerase and $\left[{ }^{32} \mathrm{P}\right] U T \mathrm{~T}$ as described by the manufacturer. The labeled RNA was separated from unincorporated UTP using phenol/chloroform followed by chloroform extractions and ethanol precipitation. Hybridization to RNA was carried out at $65^{\circ} \mathrm{C}$ in a solution composed of $50 \%$ formamide, $5 \times$ standard saline citrate (SSC) ${ }^{1}$ (SSC is $0.15 \mathrm{M}$ sodium chloride and $0.015 \mathrm{M}$ sodium citrate, $\mathrm{pH} 7.0$ ), $1 \times \mathrm{PE},(\mathrm{PE}$ is $50 \mathrm{mM}$ Tris, $\mathrm{pH} 7.5$, $0.1 \%$ sodium pyrophosphate, $1 \%$ SDS, $0.2 \%$ polyvinylpyrolidone, $0.2 \%$ Ficoll, $5 \%$ EDTA, $1 \% \mathrm{BSA}$ ), and $150 \mu \mathrm{g} / \mathrm{ml}$ denatured salmon sperm DNA. The probe was included at $10^{6} \mathrm{cpm} / \mathrm{ml}$. Filters were washed twice in $2 \times \mathrm{SSC}$ and $0.1 \%$ SDS at $65^{\circ} \mathrm{C}$ and twice in $0.1 \times \mathrm{SSC}, 0.1 \%$ SDS at $65^{\circ} \mathrm{C}$, and twice in $0.1 \times \mathrm{SSC}$ and $0.1 \% \mathrm{SDS}$ at $65^{\circ} \mathrm{C}$ (each wash wash for $15 \mathrm{~min}$ ).

For Glut 4 the cRNA probe was the entire 2.49-kb EcoRI fragment of the rat muscle glucose transporter cDNA which had been subcloned into the Bluescript $\mathrm{KS}$ vector (Stratagene Inc.) and linearized with SalI. Antisense RNA was synthesized as above, and hybridizations were carried out in $50 \%$ formamide, $5 \times$ SSC, $5 \times$ Denhardt's solution ( $1 \times$ Denhardt's solution is $0.02 \%$ polyvinylpyrolidone, $0.02 \%$ Ficoll, $0.02 \%$ BSA), $50 \mathrm{mM}$ phosphate buffer (pH 7.0), $1 \% \mathrm{SDS}, 100 \mu \mathrm{g} / \mathrm{ml}$ poly(A), $5 \mathrm{mM}$ EDTA at $60^{\circ} \mathrm{C}$ for $16-20 \mathrm{~h}$. The probe was included at $1-2 \times 10^{6}$ $\mathrm{cpm} / \mathrm{ml}$. Filters were washed in $0.1 \times \mathrm{SSC}$ and $0.1 \%$ SDS at $65^{\circ} \mathrm{C}$.

Northern blots were also probed with a random-primed $\beta$-actin cDNA. Hybridization was carried out at $42^{\circ} \mathrm{C}$ in a solution containing $50 \%$ formamide, $5 \times$ sodium chloride sodium phosphate EDTA buffer (SSPE) $\left(0.9 \mathrm{M} \mathrm{NaCl}, 5 \mathrm{nM}\right.$ EDTA and $\left.50 \mathrm{mM} \mathrm{NaH}_{2} \mathrm{PO}_{4}, \mathrm{pH} 7.4\right)$, $0.2 \%$ SDS, $0.1 \%$ each of BSA, polyvinyl-pyrolidine, and Ficoll and denatured, sperm DNA $(200 \mu \mathrm{g} / \mathrm{ml})$. The probe was included at $10^{6}$ $\mathrm{cpm} / \mathrm{ml}$. Blots were washed in SSPE and $0.1 \%$ SDS at $24^{\circ} \mathrm{C}$ (three washes of $10 \mathrm{~min}$ each), and then in $0.1 \times$ SSPE and $0.1 \%$ SDS at $50-55^{\circ} \mathrm{C}$ (three washes of $30 \mathrm{~min}$ each). They were then exposed to Kodak XAR- 5 films with an intensifying screen at $-70^{\circ} \mathrm{C}$. The abundance of specific glucose transporter or actin message was quantitated by densitometric scanning of the autoradiograms using a densitometer (Hoefer Scientific Instruments, San Francisco, CA). The areas under the curves were calculated using a Hoefer G S 350 computer program.

Analysis of protein. Protein was determined by the coomassie brilliant blue method (protein assay [Bio-Rad Laboratories, Richmond, CA]) using crystalline bovine serum albumin as the standard (33).

Analysis of glucose and insulin. At decapitation of the fed rats, blood was sampled for analysis of plasma insulin by conventional radioimmunoassay and glucose by a glucose oxidase method (glucose analyzer) (Yellow Springs Instruments Co., Yellow Springs, $\mathrm{OH}$ ).

Presentation of data. As previously reported (11), the enlargement of fat cells from hyperinsulinemic fa/fa rats is accompanied by a severalfold increase in total membrane protein and a comparable increase in total cellular RNA. These changes in total protein and RNA per cell must be considered when studying the relative abundance of specific proteins and mRNAs in fat cells with different size. In both Western immunoblotting and in Northern blot hybridization experiments we loaded equal amount of total protein and total RNA, respectively, in each lane on the gels. Although the blots then represent the same amount of protein or RNA from lean and obese rats, they reflect different numbers of adipocytes. To interpret our data in a more physiologically meaningful way, we have expressed the concentrations of total membrane protein and total cellular mRNA, as well as the glucose uptake rate, per adipocyte. Thus we consider the expression per cell to be the most internally consistent, functionally informative, and physiologically appropriate.

Specific mRNA or protein levels per cell were calculated by multiplying the optical density corresponding to the signal on Northern or Western blots (loaded with equal amounts of RNA or protein) by the relative amount of protein or RNA/cell yielding specific protein or mRNA/adipocyte. In the present investigation we also checked the loading procedure both by UV shadowing of ethidium bromide stained RNA and measurement of the $\beta$-actin transcripts. It appeared that mRNA encoding $\beta$-actin could not be used in normalizing the specific mRNAs of glucose transporters in this study, since the mRNA for actin was substantially and reproducibly altered in the obese animals. Previously, it has been shown that short term in vitro exposure of rat hepatoma cells to insulin induces a twofold increase in $\beta$-actin mRNA (34) and studies of the effects of fasting and refeeding on rat adipose cells revealed pronounced alterations in actin mRNA (35).

Statistical analyses. Results are presented as mean \pm standard error of the mean, with differences within and between groups tested by analysis of variance and by Wilcoxon's two-sample test. Spearman's coefficient of rank was applied in correlation studies. Spearman's coefficient of rank was applied in correlation studies.

\section{Results}

Characteristics of experimental animals. Some of the characteristics of the two different phenotypes of Zucker rats are given in Table I. The 5-wk obese Zucker rats were slightly hyperinsulinemic, and their body weight and epididymal fat pad weights were heavier than those of their lean littermates. The relative hyperinsulinemia increased in the obese animals with age from $153 \%$ of control levels at $5 \mathrm{wk}$, to $553 \%$ at $10 \mathrm{wk}$ and $1,370 \%$ at $20 \mathrm{wk}$. In the 20-wk-old obese rats streptozotocin-induced diabetes for $36 \mathrm{~h}$ caused a $77 \%$ decline in the plasma insulin levels (although insulin levels were still $76 \%$ above normal) and a fourfold increase in the plasma glucose concentrations.

The effects of age, obesity, and diabetes on cell volume, total protein, and total RNA in isolated epididymal adipocytes are shown in Table II. In both the lean and obese rats, the fat cell volume increased with age, but, on average, the volume of fat cells was four- to sixfold greater in obese rats when compared with lean rats. The enlargement of adipocytes from obese animals was accompanied by a three- to ninefold increase in total membrane protein recovered per cell, and a two- to fivefold increase in total RNA per cell. The mRNA encoding the

Table I. Characteristics of Zucker Rats

\begin{tabular}{|c|c|c|c|}
\hline & Lean & & Obese \\
\hline \multicolumn{4}{|l|}{$5 \mathrm{wk}$} \\
\hline Number & 32 & & 20 \\
\hline Body weight (g) & $124 \pm 16$ & & $147 \pm 9$ \\
\hline Epididymal fat pads (g) & $0.4 \pm 0.1$ & & $1.2 \pm 0.2^{*}$ \\
\hline p-glucose (mmol/liter) & $7.9 \pm 1.9$ & & $8.1 \pm 2.2$ \\
\hline$p$-insulin $(\mu \mathrm{U} / \mathrm{ml})$ & $19 \pm 9$ & & $29 \pm 14$ \\
\hline \multicolumn{4}{|l|}{$10 \mathrm{wk}$} \\
\hline Number & 10 & & 10 \\
\hline Body weight (g) & $271 \pm 16$ & & $338 \pm 22$ \\
\hline Epididymal fat pads (g) & $2.1 \pm 0.3$ & & $7.2 \pm 1.6^{*}$ \\
\hline p-glucose (mmol/liter) & $6.9 \pm 2.3$ & & $7.7 \pm 1.7$ \\
\hline \multirow[t]{2}{*}{$p$-insulin $(\mu \mathrm{U} / \mathrm{ml})$} & $17 \pm 6$ & & $105 \pm 33^{*}$ \\
\hline & Lean & Obese & Diabetic \\
\hline \multicolumn{4}{|l|}{20 wk } \\
\hline Number & 12 & 13 & 11 \\
\hline Body weight (g) & $416 \pm 64$ & $586 \pm 43$ & $552 \pm 48$ \\
\hline Epididymal fat pads (g) & $4.4 \pm 0.4$ & $14.2 \pm 1.6^{*}$ & $14.2 \pm 1.4^{*}$ \\
\hline p-glucose (mmol/liter) & $8.5 \pm 2.8$ & $7.5 \pm 2.2$ & $29.7 \pm 7.3^{*}$ \\
\hline$p$-insulin $(\mu \mathrm{U} / \mathrm{ml})$ & $34 \pm 23$ & $261 \pm 108^{*}$ & $60 \pm 31^{*}$ \\
\hline
\end{tabular}

* Difference from age-matched lean control rats at $P \leq 0.05$. 
Table II. Characteristics of Fat Cells from Zucker Rats

\begin{tabular}{|c|c|c|c|}
\hline & Lean & & Obese \\
\hline \multicolumn{4}{|l|}{5 wk } \\
\hline Adipocyte volume (pl) & $25 \pm 5$ & & $125 \pm 17^{*}$ \\
\hline \multicolumn{4}{|l|}{$\begin{array}{l}\text { Total membrane protein } \\
\text { recovered/adipocyte }\end{array}$} \\
\hline (pg) & $80 \pm 1$ & & $774 \pm 28^{*}$ \\
\hline \multicolumn{3}{|l|}{ Total RNA/adipocyte } & $28 \pm 1^{*}$ \\
\hline $\begin{array}{l}\beta \text {-actin mRNA/adipocyte } \\
\text { (arbitrary units, \% of } \\
5 \text { wk lean rats) }\end{array}$ & 100 & & $397 \pm 71^{*}$ \\
\hline \multicolumn{4}{|l|}{$10 \mathrm{wk}$} \\
\hline Adipocyte volume (pl) & $109 \pm 6$ & & $628 \pm 52^{*}$ \\
\hline \multicolumn{4}{|l|}{ Total membrane protein } \\
\hline \multicolumn{3}{|l|}{ Total RNA/adipocyte } & $32 \pm 3^{*}$ \\
\hline \multirow[t]{2}{*}{$\begin{array}{l}\beta \text {-actin mRNA/adipocyte } \\
\text { (arbitrary units, \% of } \\
5 \text { wk lean rats) }\end{array}$} & $178 \pm 20$ & & $586 \pm 41^{*}$ \\
\hline & Lean & Obese & Diabetic \\
\hline \multicolumn{4}{|l|}{$20 \mathrm{wk}$} \\
\hline Adipocyte volume (pl) & $252 \pm 14$ & $1188 \pm 120^{*}$ & $1134 \pm 120^{*}$ \\
\hline $\begin{array}{l}\text { Total membrane protein } \\
\text { recovered/adipocyte } \\
\text { (pg) }\end{array}$ & $320 \pm 17$ & $1346 \pm 16^{*}$ & $1139 \pm 58^{*}$ \\
\hline $\begin{array}{l}\text { Total RNA/adipocyte } \\
\text { (pg) }\end{array}$ & $12 \pm 1$ & $26 \pm 1^{*}$ & $24 \pm 1^{*}$ \\
\hline $\begin{array}{l}\beta \text {-actin mRNA/adipocyte } \\
\text { (arbitrary units, \% of } \\
5 \text { wk lean rats) }\end{array}$ & $278 \pm 22$ & $780 \pm 85^{*}$ & $671 \pm 106^{*}$ \\
\hline
\end{tabular}

* Difference from age-matched lean control rats at $P \leq 0.05$

cytoskeletal protein $\beta$-actin was also substantially altered by age and obesity (Table II).

Glucose conversion to lipid in isolated fat cells and effects of insulin. In lean Zucker rats both basal and total (basal plus insulin stimulated) glucose conversion to lipid per adipocyte increased by threefold as the animals went from an age of 5 wk to the age of $20 \mathrm{wk}(P<0.05)$ (Fig. 1, left bar in each age group). Simultaneously, the maximal insulin response above the basal

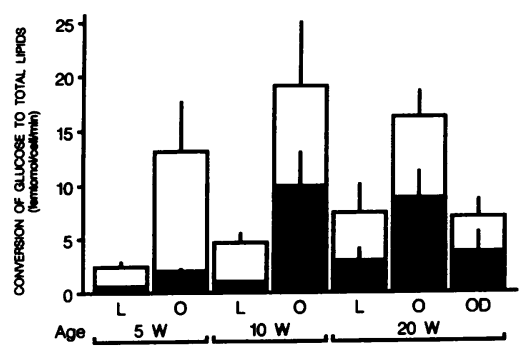

Figure 1. Conversion rates of glucose to lipids in basal (closed bars) and maximally insulin-stimulated (open bars) adipocytes from lean $(L)$, obese $(O)$, and obese diabetic $(O D)$ rats at 5,10 , and 20 wk of age. Isolated fat cells were prepared from the epididymal fat pads from the rats (Table I), and preincubated for 45 min at $37^{\circ} \mathrm{C}$ in the absence or presence of $1 \mu \mathrm{M}$ insulin. Thereafter, the conversion of trace amounts of glucose $(1.5 \mu \mathrm{M})$ to lipids was measured for the next $60 \mathrm{~min}$ as described in Methods. Results are mean \pm SEM of four separate experiments in each age group.

value declined slightly as a function of age $(440 \pm 41 \%$ at $5 \mathrm{wk}$ and $264 \pm 35 \%$ at 20 wk, $P=0.07$ ).

In obese Zucker rats both basal and total glucose conversion to lipid was three- to fivefold higher per fat cell at all ages when compared with the findings in lean animals $(P<0.05)$ (Fig. 1, right bar in each age group). Basal glucose conversion rate in cells from obese rats increased dramatically, about fivefold, from the age of $5 \mathrm{wk}$ to the age of $10 \mathrm{wk}(P<0.05)$ with no further change thereafter. (Fig. 1). Total glucose conversion rate in fat cells from obese animals showed no significant change among the three age groups; however, there was a decline of maximal insulin response above basal value as a function of age going from $605 \pm 67 \%$ at 5 wk to $157 \pm 26 \%$ at 20 wk $(P<0.05)$. In other words, when compared with lean controls, adipose cells from 5-wk-old obese rats were hyperresponsive to insulin, whereas fat cells from 20 -wk-old obese rats were insulin resistant. Acute streptozotocin-induced diabetes in 20-wkold obese rats caused a significant reduction in both basal and total glucose uptake $(P<0.05)$ (Fig. 1).

Table III shows the glucose conversion rates when expressed per unit cellular surface area. It appears from this way of expressing the data that there is a significant difference in total (basal plus insulin stimulated) glucose uptake at age $5 \mathrm{wk}$ between lean and obese Zucker rats, whereas, at age 10 and 20 wk the difference has disappeared. However, even when the data are expressed per surface area, 5 wk obese rats exhibit insulin hyperresponsive glucose uptake $(P<0.05)$ and 20 wk obese rats show insulin resistant uptake $(P<0.05)$ when compared with age-matched controls.

Immunodetectable concentrations of glucose transporter proteins in adipocytes. The amount of Glut 1 and Glut 4 proteins in a crude membrane preparation from isolated adipose cells was quantitated by Western blotting, using specific anti-

Table III. Conversion of Glucose to Total Lipids

\begin{tabular}{|c|c|c|c|c|c|c|c|}
\hline & \multicolumn{2}{|c|}{ 5-wk-old rats } & \multicolumn{2}{|c|}{ 10-wk-old rats } & \multicolumn{2}{|c|}{20 -wk-old rats } & \multirow[b]{2}{*}{ Diabetic } \\
\hline & Lean & Obese & Lean & Obese & Lean & Obese & \\
\hline \multicolumn{8}{|c|}{$\mathrm{mol} / \mu \mathrm{m}^{2}$ per $\min \left(\times 10^{20}\right)$} \\
\hline \multicolumn{8}{|l|}{ Basal } \\
\hline $12.8 \pm 1.6$ & $16.3 \pm 2.3$ & $9.2 \pm 2.5$ & $24.8 \pm 9.0$ & $15.5 \pm 3.6$ & $18.6 \pm 4.2$ & $7.3 \pm 2.7^{*}$ & \\
\hline+ Insulin $(1 \mu \mathrm{M})$ & $50.8 \pm 4.6$ & $102.5 \pm 6.2^{*}$ & $44.2 \pm 5.9$ & $48.5 \pm 10.1$ & $40.0 \pm 6.1$ & $30.7 \pm 4.9$ & $13.3 \pm 2.4^{*}$ \\
\hline
\end{tabular}

Results are mean \pm SEM of four separate experiments in each age group.

* Difference from age-matched lean rats at $P \leq 0.05$ 
Glut 1

\section{Autoradiograms \\ of Immunoblottings}

\section{Scanning of Autoradiograms (optical density units $\times 10^{3}$ )}

Total Membrane Protein recovered per Fat Cell (pg)

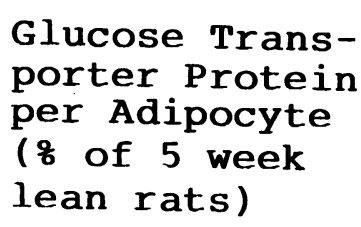

Glucose Trans-
porter Protein
per Adipocyte
( 8 of 5 week
lean rats)

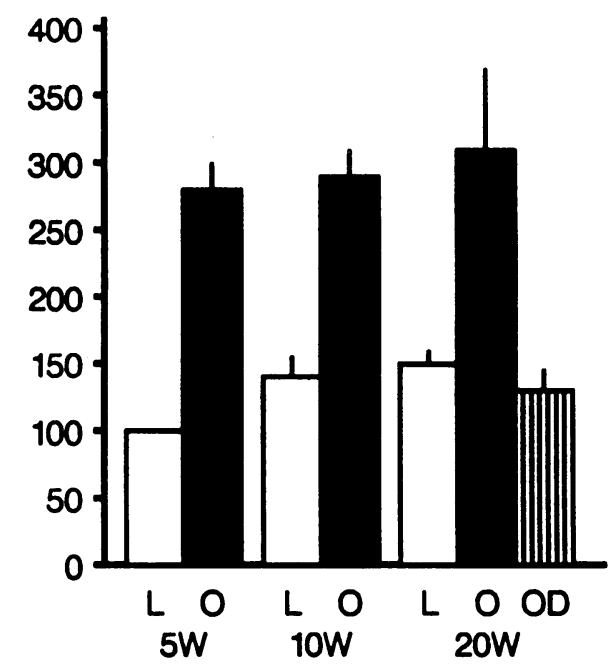

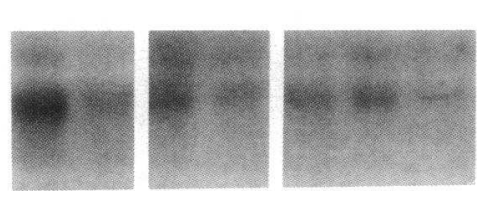
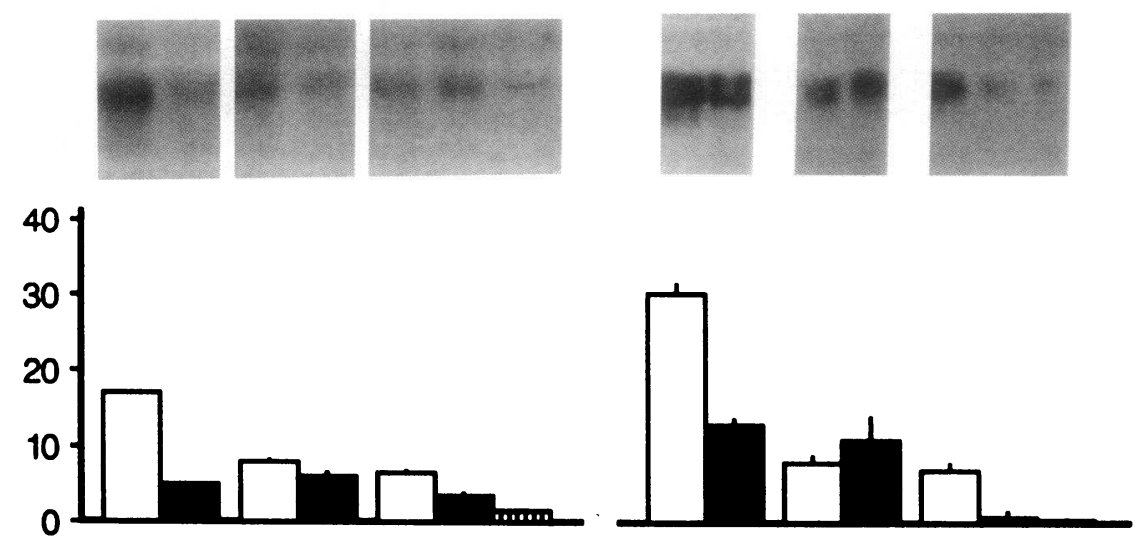

Glut 4
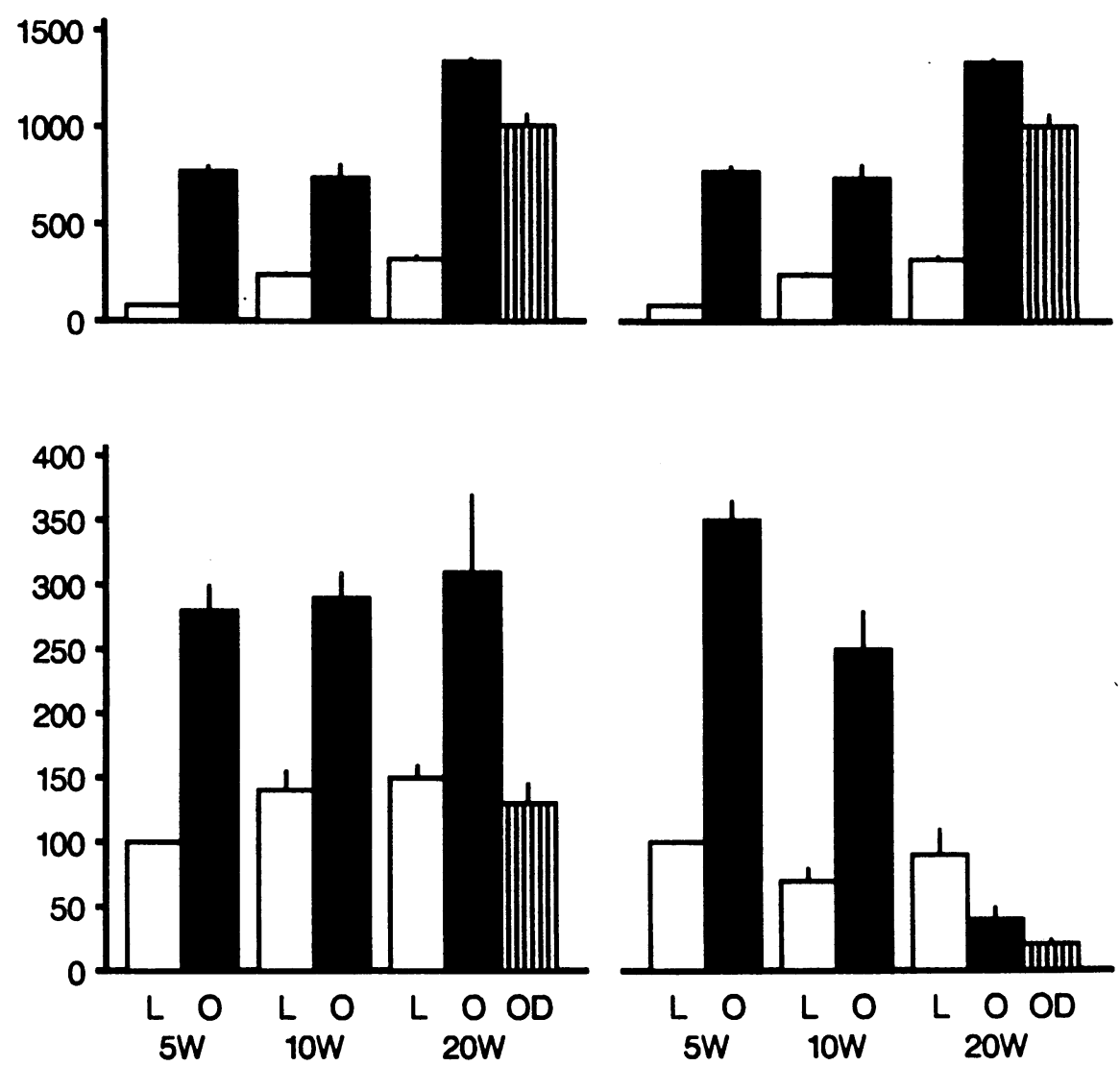

Figure 2. Representative autoradiograms of immunoblotting of Glut 1 and Glut 4 protein (1. panels from the top) in isolated adipocytes from lean $(L)$, obese $(O)$, and obese diabetic $(O D)$ Zucker rats at 5, 10, and 20 wk of age (Table I). Fat cell membrane protein was prepared, and gel electrophoresis, immunoblotting, and densitometric scanning were carried out as described in Methods. Each lane contains $100 \mu \mathrm{g}$ membrane protein in Glut 1 experiments, and $65 \mu \mathrm{g}$ in Glut 4 experiments. Second panels from the top give the values obtained by scanning of the individual autoradiograms, and third panels from the top show the adipocyte levels of membrane protein. The Glut 1 and Glut 4 protein levels per adipocyte as expressed in percent of values in 5 wk-lean Zucker rats are given in the bottom panels. Results are mean \pm SEM of four separate experiments in each age group.

sera against each glucose transporter. Both antisera identified dominant protein bands with an apparent $M_{\mathrm{r}}$ of $45-50 \mathrm{kD}$, the size of which was unaffected by age, obesity, or diabetes (Fig. 2).

When equal amounts of membrane protein were loaded in each lane of the gel there appeared to be a decrease in both Glut
1 and Glut 4 with increasing age and with obesity (Fig. 2, top). However, the amount of membrane protein in fat cells increases as a function of age and adiposity (Table II and Fig. 2, middle). When these differences are taken into account, and the data are expressed as a percent of 5-wk-lean Zucker rats, several findings are apparent (Fig. 2, bottom). First, lean rats at 
5 and 10 wk exhibit similar levels of both Glut 1 and Glut 4 per fat cell, and at $20 \mathrm{wk}$, Glut 1 protein per cell increases modestly (50\%) compared with 5-wk-old controls. Strikingly, adipocytes from obese rats contain three times more Glut 1 protein per cell than their lean littermates (Fig. 2$)(P<0.05)$. In obese rats, levels of Glut 1 protein per adipocyte are unaffected by age.
Finally, acute diabetes in 20-wk-old obese rats is associated with a $60 \%$ decrease in the Glut 1 protein level per adipocyte (Fig. 2) $(P<0.05)$.

Age-related changes in the level of the Glut 4 protein per adipocyte in obese animals contrast with these for Glut 1 (Fig. 2). Thus, 5 -wk-old obese rats have 3.5 times more Glut 4 pro-
Glut 1

\section{Autoradiograms \\ of Northern \\ Blottings}

\section{Scanning of} Autoradiograms (optical density units $\times 10^{3}$ )

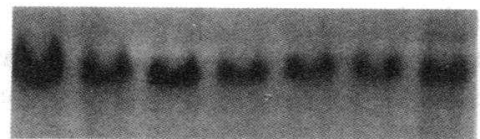

Glut 4
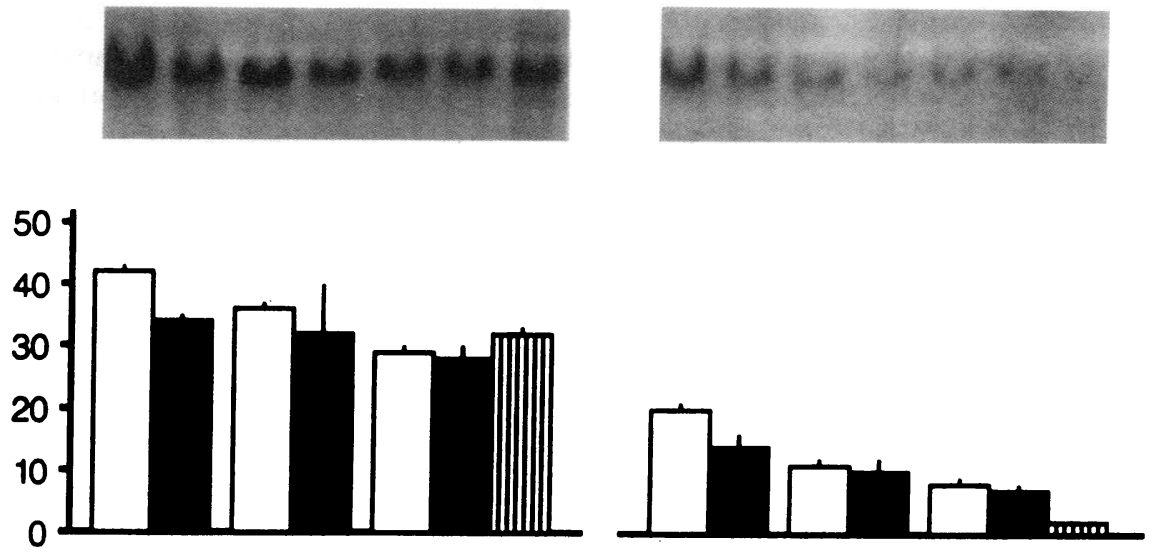

Total RNA

per Adipocyte

(pg)

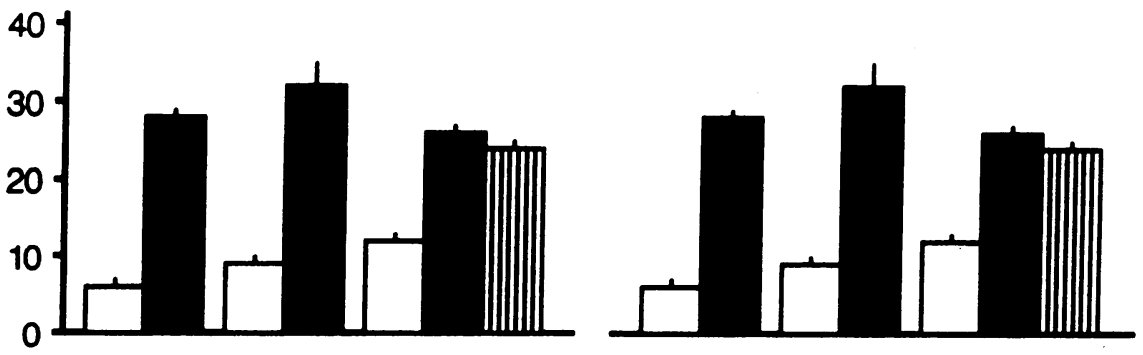

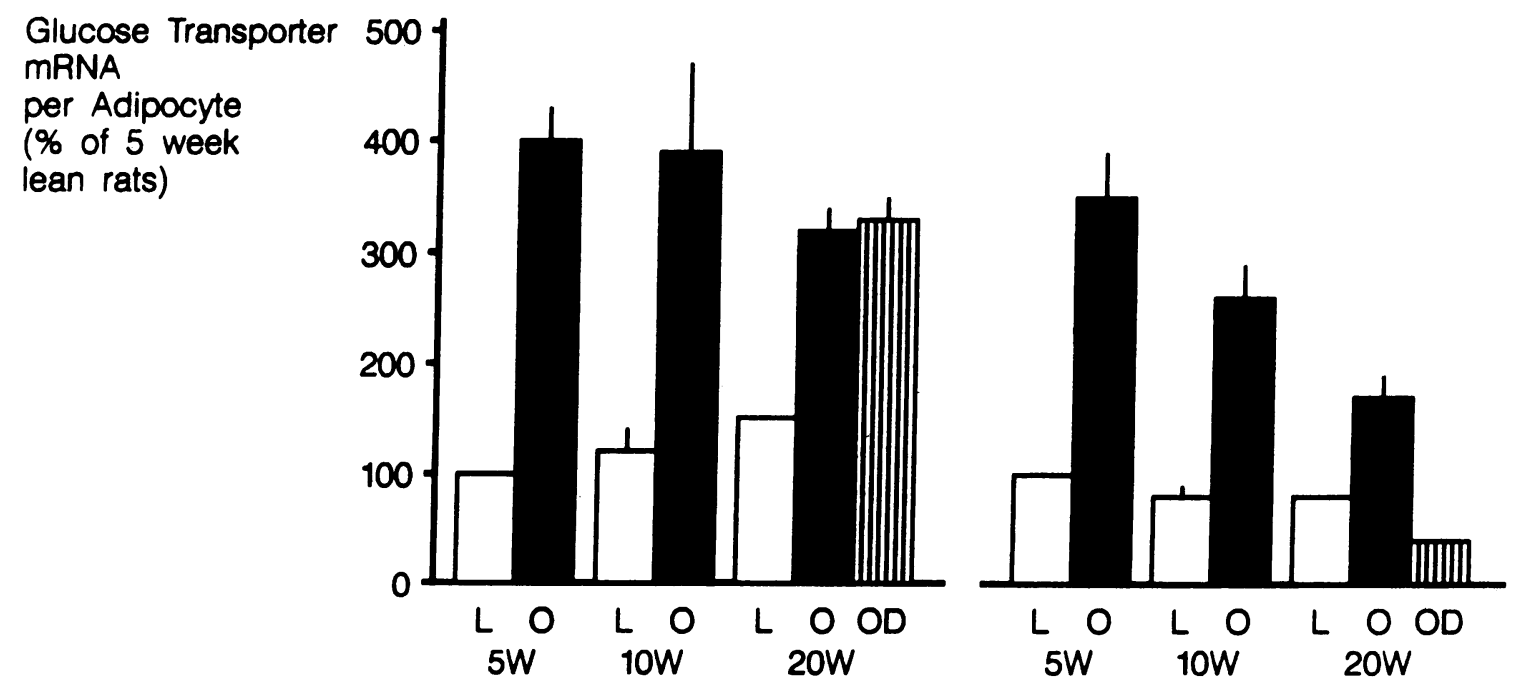

Figure 3. Representative autoradiograms of Northern blot analysis of Glut 1 and Glut 4 mRNA (1. panels from the top) in isolated adipocytes from lean $(L)$, obese $(O)$, and obese diabetic $(O D)$ Zucker rats at 5, 10, and 20 wk of age (Table I). Adipocytes were isolated, and RNA extraction, gel electrophoresis, hybridization, and scanning densitometry were performed as also described in Methods. Each lane contains $20 \mu \mathrm{g}$ total RNA. Second panels from the top give the values obtained by scanning of the individual autoradiograms, and third panels from the top show the adipocyte levels of total RNA. The Glut 1 and Glut 4 mRNA levels per adipocyte as expressed in percent of values in 5 wk-lean Zucker rats are given in the bottom panels. Results are mean \pm SEM of four separate experiments in each age group. 
tein/cell than lean littermates $(P<0.05)$. At 10 wk the fold difference has decreased to 2.5. Most remarkably, in the 20-wkold obese rats, the Glut 4 protein concentration per adipocyte is significantly lower than in the age-matched lean animals $(P$ $<0.05$ ). Acute diabetes causes a further decrease of Glut 4 protein in 20-wk-old obese Zucker rats.

Glucose transporter specific $m R N A$ concentrations in adipocytes. RNA was analyzed using Northern gel blot technique under high stringency hybridization conditions with ${ }^{32} \mathrm{P}-\mathrm{la}-$ beled Glut 1 and Glut 4 probes. Both glucose transporter probes hybridized specifically to RNA from isolated fat cells and showed single bands of $\sim 2.8 \mathrm{~kb}$, the size of which was unaltered by age, obesity, and diabetes (Fig. 3). Loading equal amounts of total RNA in each lane on the Northern gel, there was a slight reduction (20-30\%) in the amount of mRNA for Glut 1 and Glut 4 in fat cells from 5-wk-old obese Zucker rats. There was also a decline in Glut 4 with age, but no difference between lean and obese at older ages (Fig. 3). When the marked differences in total RNA/cell are taken into account (Table II and Fig. 3), again both Glut 1 and Glut 4 expression appear relatively constant in lean Zucker rats, although there is a $50 \%$ increase in Glut $1 \mathrm{mRNA}$ per cell $(P<0.05)$ in 20 -wk-old lean rats. Adipose cells from obese rats express three to four times more Glut $1 \mathrm{mRNA}$ per cell than their lean littermates $(P$ $<0.05$ ) without any significant alterations during aging or following induction of streptozotocin diabetes (Fig. 3). At all ages Glut 4 mRNA expression per cell was increased in obese rats $(P$ $<0.05$ ) with a 3.5 -fold increase at $5 \mathrm{wk}$ and a gradual decline to a 1.7 -fold increase at $20 \mathrm{wk}$. Acute, streptozotocin-induced diabetes resulted in a marked decrease in Glut 4 mRNA per cell $(P$ $<0.05$ ) in 20-wk-old obese rats (Fig. 3).

Thus, the patterns of mRNA closely correlated with the pattern of protein expression. There were only two minor exceptions. First, although both Glut 4 protein and mRNA per cell were increased in obesity and fell with age, mRNA levels per cell remained above lean control at all ages, whereas protein level per cell fell below the lean control at $20 \mathrm{wk}$ of age.
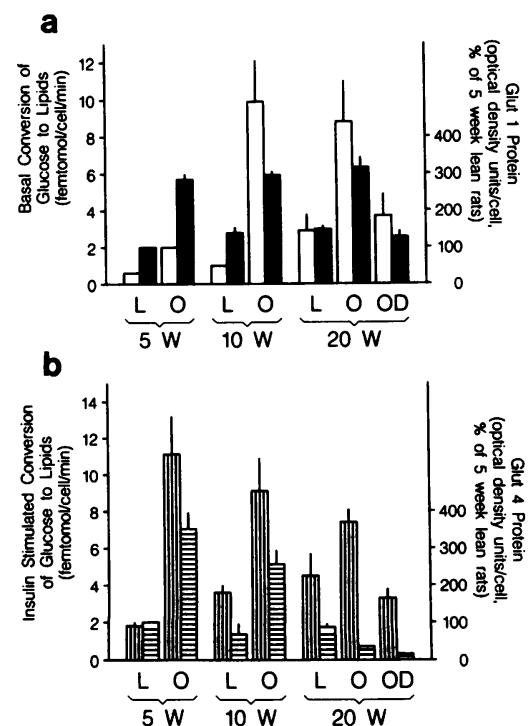

Figure 4. (a) A comparison of basal conversion rates of glucose to lipids () and Glut 1 protein concentration $(\square)$ in adipose cells from lean $(L)$, obese $(O)$, and obese diabetic $(O D)$ Zucker rats at 5,10 , and $20 \mathrm{wk}$ of age. Values are mean \pm SEM and are derived from Figs. 1 and 2 , respectively. (b) A comparison of insulin-stimulated (total minus basal) conversion rates of glucose to lipids $(\square)$ and Glut 4 protein concentrations $(\square)$ in adipose cells from lean $(L)$, obese $(O)$, and obese diabetic $(O D)$

Zucker rats at 5,10 , and $20 \mathrm{wk}$ of age. Values are mean \pm SEM and are derived from Figs. 1 and 2, respectively.
Secondly, in acute streptozotocin diabetes, there was a fall in Glut 1 protein per cell without a fall in mRNA per cell.

Comparison of Glut 1 and Glut 4 protein levels to glucose conversion rates in adipocytes. In Fig. 4 we have compared basal conversion rate of glucose to lipid with Glut 1 protein concentration $(a)$ and insulin stimulated (total - basal) glucose conversion rate with Glut 4 protein concentration $(b)$. All data are expressed per cell. It is clear that Glut 1 protein level tends to parallel basal glucose conversion rate. In obese rats both basal uptake rate and Glut 1 protein are increased, and both decrease in the presence of acutely induced diabetes. This tendency was confirmed by correlation analysis $(r=0.89, P$ $=0.05$ ). In younger ( 5 and $10 \mathrm{wk}$ ) Zucker rats there was also a strong positive correlation between insulin-stimulated glucose uptake rate and Glut 4 protein levels. This correlation, however, does not hold in the 20-wk-old animals. In these there is a relative maintenance of uptake activity despite markedly reduced levels of Glut 4 protein in obesity, and especially in the obese diabetic rat.

\section{Discussion}

Previous studies have utilized the Zucker fatty rat as a model of obesity and insulin resistance and have shown profound alterations in adipocyte glucose utilization in these animals (1-11, 36). Adipose cells from obese Zucker rats are characterized by a severalfold higher total (basal plus maximal insulin stimulated) glucose uptake rate than adipose cells from lean littermates. This enhanced total glucose uptake rate is independent of changes in age and cell size. However, changes between basal and insulin-stimulated adipocyte glucose uptake rate occur as a function of age. Thus, 5-wk-old obese rats exhibit insulin hyperresponsive glucose uptake, whereas 20 -wk-old obese rats show insulin-resistant glucose uptake (1-7). Since glucose transporters are prime candidates for regulation of adipose cell glucose turnover, we have studied the adipocyte content of transcriptional and translational products of the Glut 1 and Glut 4 genes in genetically obese rats at 5,10 , and 20 wk of age. Moreover, we have treated 20 -wk-old obese Zucker rats with streptozotocin to acutely induce relative insulin deficiency and hyperglycemia. We find that the two types of glucose transporters in the same adipose cell are differentially regulated under the same conditions of obesity and diabetes.

Since adipose cells from 10 and 20 wk obese Zucker rats are readily ruptured by centrifugation, 3- $O$-methylglucose transport or total fat cell-associated radioactivity $(27,28)$ could not be determined. This same problem was stated by Ezaki (36) in 13-wk-old obese Zucker rats. Previous studies have shown that about $60 \%$ of glucose taken up by fat cells of varying size are converted into total lipids $(27,28)$. Consequently, we have measured lipogenesis rate in fat cells at experimental conditions of a low trace concentration of glucose where glucose transport has been shown to be rate limiting for lipogenesis (27). It may be argued that the ratios between various metabolic pathways of fat cells may be different between lean and obese rats, and especially in the aged rats. Thus, we cannot ignore the possibility that the lipogenesis results may over- or underestimate the glucose transport rates. However, our lipogenesis data closely parallel previous reports that glucose transport or glucose metabolism are increased in fat cells from both young and old fa/fa Zucker rats when compared with lean littermates $(4,5,11)$. Furthermore, the glucose uptake results are 
not the novel part of the present paper and are provided only to enable interpretation of the transporter mRNA and protein levels in a physiologically significant way.

Glut 4 is the major transporter believed to be responsible for the glucose uptake response to insulin in adipose cells (1720). Interestingly, as a result of a general increase in total membrane protein and total RNA in adipose cells from obese Zucker rats, we find an increased expression of Glut 4 both at mRNA and protein levels per cell from young obese rats. Moreover, we find a gradual decline in Glut 4 expression per cell as a function of age which is especially dramatic at $20 \mathrm{wk}$ of age. Our findings in 5-wk-old rats are consistent with a previous report (11) that in this early stage of obesity in Zucker rats, the enhanced glucose utilization rate in adipocytes is associated with an increase of the number of glucose transporters estimated by cytochalasin B binding. The increased cytochalasin B binding in young obese Zucker rats was demonstrated only when differences in fat cell membrane protein between lean and obese rats were accounted for (11). This observation is in accordance with our present finding. In contrast, Hainault et al. (37) recently reported that the abundance of Glut 4 protein per milligram of total membrane protein in adipocytes from 16- and 30-d-old obese Zucker rats was 2.4- and 4.5-fold greater than those of lean littermates, respectively. It is not clear why this recent report found the difference in Glut 4 levels even before taking into account increases in membrane protein per cell, as was necessary in the study by Guerre-Millo et al. (11) and in our study. However, all these studies are in agreement that changes in the abundance of Glut 4 may account at least in part for the insulin hyperresponsive glucose uptake in adipose cells of young obese rats.

There is a positive correlation between Glut 4 expression and insulin-stimulated glucose uptake in the 5- and 10-wk-old animals, but not in 20-wk-old rats or after streptozotocin-induced diabetes. Since most of Glut 4 protein in the resting (basal) state are located in an intracellular pool, and transporters affect glucose transport into the cell only when translocated to the plasma membrane (38), it is possible that changes in translocation or in the ratio of Glut 4 proteins in the two pools may contribute to the observed changes in insulin responsiveness in the older or diabetic animals. The decrease we see in Glut 4 in adipose cells of 20 wk obese Zucker rats is in agreement with a recent study in obese and aged (12-mo-old) Sprague-Dawley rats, which found Glut 4 protein to be severely decreased in both the plasma membrane and the intracellular pool under basal, as well as insulin-stimulated, conditions (39). Furthermore, it is possible that alterations in the intrinsic activity of the glucose transporters contribute to the discrepancies between Glut 4 protein level and insulin-stimulated glucose transport (38).

Glut 1 is much less abundant in adipocytes than Glut 4, and insulin stimulates translocation of Glut 1 to the cell surface only 1-2-fold compared with about 10-fold for Glut 4 (38). Glut 1 in adipose cells is therefore considered to be primarily a constitutive glucose transporter with little contribution to the effect of insulin. Consistent with this, we find a positive correlation between basal glucose uptake and the Glut 1 protein level per cell. When adjusting for differences in membrane protein and total RNA per fat cell, the abundance of Glut $1 \mathrm{mRNA}$ and protein is three to four times higher in adipocytes from obese Zucker rats than in lean littermates, paralleling the increase in basal glucose uptake. In contrast to the alterations of Glut 4 expression during the evolution of obesity, there is no change in Glut 1 expression. Hainault et al. found in 16- and 30-d-old $\mathrm{fa} / \mathrm{fa}$ Zucker rats on a per cell basis roughly unchanged levels of Glut 1 protein (37). It may, however, be difficult to compare the results, since these authors did not give data for total membrane protein per fat cell (37).

The physiologic effect of the increased expression of Glut 1 in adipocytes from obese rats is unclear, but this transporter may contribute to a persistent increase in glucose uptake rate. This may especially be the case in 20-wk-old insulin resistant obese rats, where the estimated number of immunoreactive Glut 4 transporters is downregulated but Glut 1 expression is unchanged, and total glucose uptake remains increased relative to lean animals. In a recent study comparing the subcellular distribution of Glut 1 protein in noninsulin-stimulated adipose cells from young (1 mo old) and aged (12 mo old) SpragueDawley rats, there was a 2.8 -fold increase in Glut 1 per fat cell in the plasma membranes of the older rats (39).

This longitudinal study of lean Zucker rats shows how growth and aging affect adipocyte glucose uptake and content of glucose transporters. Both basal and total glucose uptake rate increase as a function of age and fat cell enlargement, and are accompanied by a similar increase in the cellular content of Glut 1 but not of Glut 4 mRNA and protein. In the 20-wk-old lean Zucker rat, adipocyte glucose uptake is relatively insulin resistant when compared with findings in young lean rats. This decrease in insulin-stimulated glucose uptake in fat cells from 20-wk-old lean animals may be related to impaired translocation or intrinsic activity of Glut 4 with a compensatory increase in Glut 1 expression and/or function.

Our present results show that the expression of the cytoskeletal protein $\beta$-actin is altered as well in adipose cells from genetic obese rats. Previous in vivo and in vitro experiments, including studies in adipose cells $(20,34,35)$, have shown that ambient insulin levels may be one important factor in regulating actin mRNA in several tissues. Thus, the elevated insulinemia in the obese Zucker rats could be contributing to the increase in actin mRNA and could be part of the generalized anabolic effect of insulin. This does not change our conclusions. That is, it is not necessary for the effects on transporter expression to be selective to result in changes in transport activity. However, in the available literature on gene expression in Zucker rats, the mRNA level of the lipogenic enzyme, glyceraldehyde-3-phosphate in adipose tissue of 16 and $30 \mathrm{~d}$ obese rats is reported to be selectively increased (40).

The increases in uptake rate and transporters in obese rats at $10 \mathrm{wk}$ and the increase in uptake rate at $20 \mathrm{wk}$ are not seen when the results are expressed per surface area instead of per cell. However, in all our data presentation we have found it internally consistent and physiologically most appropriate to use the per cell denominator to compare total transport activity (intrinsic activity and translocation), total transporter protein (in the plasma membrane and the intracellular pool), and total transporter mRNA (in the cytosol and the nucleus). Moreover, even when the data are expressed per surface area our main conclusions remain unchanged. That is, we find insulin hyperresponsive glucose uptake in combination with an overexpression of Glut 4 in 5 wk obese rats and insulin resistant glucose uptake in combination with an impaired expression of Glut 4 in 20 wk obese rats.

The regulatory mechanisms behind the longitudinal changes in glucose transporters of adipocytes from lean and 
obese Zucker rats are not known. However, it has been shown that glucose transporter gene expression in adipose cells in vivo is markedly affected by altered nutritional and metabolic states. These studies lend support to the hypothesis that plasma insulin may participate in the chronic regulation of adipocyte Glut 4 expression. Thus, hypoinsulinemic states like fasting and diabetes $(20-23,35)$ are associated with a decrease in adipose cell Glut $4 \mathrm{mRNA}$ and protein concentration, whereas relative hyperinsulinemic states such as refeeding and insulin treatment $(20-23,35)$ are associated with increases in Glut 4 expression. On this background it is tempting to suggest that the slight hyperinsulinemia in 5-wk-old obese animals produces the higher steady-state level of Glut 4 mRNA and protein. Alternatively, other factors, including genetic factors, might trigger the overexpression of several proteins, including glucose transporters. In favor of the latter hypothesis is the report of an increase of body fat in fa/fa rats before a detectable rise in plasma insulin levels or hyperphagia (1). The factors behind the downregulation of Glut 4 in old obese Zucker rats are also unexplained. The fact that Glut 4 protein content per fat cell was much more decreased than the Glut 4 mRNA level points toward a major regulatory effect on steps involving the translatability of Glut $4 \mathrm{mRNA}$ or degradation of the protein.

Recent reports on the impact of streptozotocin diabetes in normal rats suggest that this type of experimental diabetes is associated with a 50-60\% loss in Glut 4 mRNA and a 50-90\% loss in Glut 4 protein in adipocytes with no major changes in Glut 1 (20-23). Induction of streptozotocin diabetes in the insulin resistant 20 wk-old fatty Zucker rat results in a significant reduction in adipocyte levels of Glut 4, but not of Glut 1 mRNA, and a further reduction in both Glut 1 and 4 protein as compared with levels in the nondiabetic fatty rat. These changes are observed rapidly after only $36 \mathrm{~h}$ of diabetes. Thus, reduction in insulin secretory capacity and the resultant deterioration of glucose tolerance further accentuate the insulin resistance at the level of Glut 4 expression.

In conclusion, these studies suggest that as a result of a general increase in total membrane protein and total RNA in adipose cells of obese Zucker rats, expression of the major insulin-responsive glucose transporter (Glut 4) is increased on a per cell basis in insulin hyperresponsive young fa/fa Zucker rats, and diminished in insulin-resistant fat cells from old fa/fa rats. Furthermore, a high abundance of Glut 1 protein per fat cell from fa/fa rats at all ages may contribute to a constantly increased total glucose uptake rate per cell. Induction of diabetes in old fa/fa rats creates a hormonal-metabolic state of hyperglycemia without severe hypoinsulinemia, which is associated with profound reductions in basal and total fat cell glucose uptake rate and protein levels for both glucose transporters. Further research into the identification of possible concurrent changes in translocation and intrinsic activity of glucose transporters in this animal model will be crucial to our understanding of the sequential alterations in basal and insulin-stimulated glucose metabolism during the evolution of obesity and diabetes mellitus.

\section{Acknowledgments}

We thank A. Rosen for expert technical assistance and G. Lademann for excellent secretarial help.

This work was supported by grants from the Danish Medical Research Council, P. Højsgaard Foundation, and Dandy Research Award to O. Petersen, National Institutes of Health (NIH) grant (DK-33201), The Joslin DERC grant (DK-36836), and Pfizer Biomedical Research Award to C. R. Kahn, National Institute on Aging Physician Scientist Award (AG-00294), and Juvenile Diabetes Foundation Grant (189833) to BBK

\section{References}

1. Zucker, L. M., and H. N. Antoniades. 1972. Insulin and obesity in the Zucker genetically obese rat "fatty". Endocrinology. 90:1320-1330.

2. Bray, G. A., and D. A. York. 1971. Genetically transmitted obesity in rodents. Physiol. Rev. 51:598-646.

3. Godbole, V., and D. A. York. 1978. Lipogenesis in situ in the genetically obese Zucker fatty rat (fa/fa): role of hyperphagia and hyperinsulinemia. Diabetologia. 14:191-197.

4. Cushman, S. W., M. J. Zarnowski, A. J. Franzusoft, and L. B. Salans. 1978. Alterations in glucose metabolism and its stimulation by insulin in isolated adipose cells during the development of genetic obesity in the Zucker fatty rat. Metab. Clin. Exp. 27(Suppl. 2):1930-1940.

5. Czech, M. P., D. K. Richardarson, S. G. Becker, C. G. Walters, W. Gitomer, and J. Heinrich. 1978. Insulin response in skeletal muscle and fat cells of the genetically obese Zucker rat. Metab. Clin. Exp. 27(Suppl. 2):1967-1981.

6. Stern, J. S., P. R. Johnson, B. R. Batchelor, L. M. Zucker, and J. Hirsch.

1975. Pancreatic insulin release and peripheral tissue resistance in Zucker obese rats fed high and low carbohydrate diets. Am. J. Physiol. 228:543-548.

7. Martin, R. J. 1974. In vivo lipogenesis and enzyme levels in adipose and liver tissues from pair-fed genetically obese and lean rats. Life Sci. 14:1447-1453.

8. York, D. A., J. Steinke, and G. A. Bray. 1972. Hyperinsulinemia and insulin resistance in genetically obese rats. Metab. Clin. Exp. 21:277-284.

9. Clearly, M. P., J. R. Vasselli, and M. R. C. Greenwood. 1980. Development of obesity in Zucker obese (fa/fa) rat in absence of hyperphagia. Am. J. Physiol. 238:284-292.

10. Rohner-Jeanrenaud, F., A. C. Hochstrasser, and B. Jeanrenaud. 1983. Hyperinsulinemia of preobese and obese fa/fa rats is partly vagus nerve mediated. Am. J. Physiol. 244:E317-E322.

11. Guerre-Millo, M., M. Lavau, J. S. Horne, and L. J. Wardzala. 1985. Proposed mechanism for increased insulin-mediated glucose transport in adipose cells from young, obese Zucker rats. J. Biol. Chem. 260:2197-2201.

12. Mueckler, M. 1990. Family of glucose transporter genes: implications for glucose homeostasis and diabetes. Diabetes. 39:6-11.

13. Mueckler, M. M., C. Caruso, S. A. Baldwin, M. Panico, I. Blench, H. R. Morris, J. W. Allard, G. E. Lienhard, and H. F. Lodish. 1985. Sequence and structure of a human glucose transporter. Science (Wash. DC). 229:941-945.

14. Birnbaum, M. J., H. C. Haspel, and O. M. Rosen. 1986. Cloning and characterization of a cDNA encoding the rat brain glucose-transporter protein. Proc. Natl. Acad. Sci. USA. 83:5784-5788.

15. Flier, J. S., M. Mueckler, A. L. McCall, and H. F. Lodish. 1987. Distribution of glucose transporter messenger RNA transcripts in tissues of rat and man. J. Clin. Invest. 79:657-661.

16. Fukumoto, H. S., S. Seino, H. Imura, Y. Seino, R. L. Eddy, Y. Fukushima, M. G. Byers, T. B. Shows, and G. I. Bell. 1988. Sequence, tissue distribution and chromosomal localization of mRNA encoding a human glucose transporter-like protein. Proc. Natl. Acad. Sci. USA. 85:5434-5438.

17. James, D. E., M. Strube, and M. Mueckler. 1989. Molecular cloning and characterization of an insulin-regulatable glucose transporter. Nature (Lond.) 338:83-87.

18. Zorzano, A., W. Wilkinson, N. Kotliar, G. Thoidis, B. E. Wadzinski, A. E. Ruoho, and P. F. Pilch. 1989. Insulin-regulated glucose uptake in rat adipocytes is mediated by two transporter isoforms present in at least two vesicle preparations. J. Biol. Chem. 264:12358-12363.

19. James, D. E., R. Brown, and P. F. Pilch. 1988. Insulin regulatable tissues express a unique insulin sensitive glucose transport protein. Nature (Lond.) 333:183-185.

20. Kahn, B. B., M. J. Charron, H. F. Lodish, S. W. Cushman, and J. S. Flier. 1989. Differential regulation of two glucose transporters in adipose cells from diabetic and insulin-treated diabetic rats. J. Clin. Invest. 84:404-411.

21. Berger, J., C. Biswas, P. P. Vicario, H. V. Strout, R. Saperstein, and P. F Pilch. 1989. Decreased expression of the insulin-responsive glucose transporter in diabetes and fasting. Nature (Lond.). 340:70-73.

22. Sivitz, W. I. S. L. DeSautel, T. Kayano, G. I. Bell, and J. E. Pessin. 1989. Regulation of glucose transporter messenger RNA in insulin-deficient states. $\mathrm{Na}$ ture (Lond.). 340:72-74.

23. Garvey, W. T., T. P. Huecksteadt, and M. J. Birnbaum. 1989. Pretranslational suppression of an insulin-responsive glucose transporter in rats with diabetes mellitus. Science (Wash. DC). 245:60-63.

24. Rodbell, M. 1964. Metabolism of isolated fat cells. I. Effects of hormones on glucose metabolism and lipolysis. J. Biol. Chem. 239:375-380.

25. Pedersen, O., E. Hjøllund, H. Beck-Nielsen, H. O. Lindskov, O. Sonne, 
and J. Gliemann. 1981. Insulin receptor binding and receptor mediated insulin degradation in human adipocytes. Diabetologia. 20:636-641.

26. Pedersen, O., and J. Gliemann. 1981. Hexose transport in human adipocytes: factors influencing the response to insulin and kinetics of methylglucose and glucose transport. Diabetologia. 20:630-635.

27. Gliemann, J., W. D. Rees, and J. A. Foley. 1984. The fate of labelled glucose molecules in the rat adipocyte. Dependence on glucose concentration. Biochim. Biophys. Acta. 804:68-76.

28. Hjøllund, E., and O. Pedersen. 1988. Transport and metabolism of D-glucose in human adipocytes. Studies of the dependence of medium glucose and insulin concentrations. Biochim. Biophys. Acta. 937:93-102.

29. Joost, H.-G., and H.-J. Steinfelder. 1982. Modulation of insulin sensitivity by adenosine. Effects on glucose transport, lipid synthesis and insulin receptors of the adipocyte. Mol. Pharmacol. 22:614-618.

30. Richelsen, B., E. Hjøllund, O. Pedersen, and N. S. Sørensen. 1985. Effects of prostaglandin $\mathrm{E}_{2}$, indomethacin and adenosine deaminase on basal and insulin-stimulated glucose metabolism in adipocytes. Biochim. Biophys. Acta. 844:359-366.

31. Glisin, V., R. Crkvenjakov, and C. Byus. 1974. Ribonucleic acid isolated by cesium chloride centrifugation. Biochemistry. 13:2633-2637.

32. Chirgwin, J. M., A. W. Przybyla, R. J. MacDonald, and W. J. Rutter. 1979. Isolation of biologically active ribonucleic acid from sources enriched in ribonuclease. Biochemistry. 18:5294-5299.

33. Bradford, M. 1976. A rapid and sensitive method for the quantitation of microgram quantities of protein utilizing the principle of protein-dye binding. Anal. Biochem. 72:248-254.

34. Taub, R., A. Roy, R. Dieter, and J. Koontz. 1987. Insulin as a growth factor in rat hepatoma cells. Stimulation of proto-oncogene expression. J. Biol. Chem. 262:10893-10897.

35. Kahn, B. B., S. W. Cushman, and J. S. Flier. 1988. Regulation of glucose transporter specific mRNA levels in rat adipose cells with fasting and refeeding. Implications for in vivo control of glucose transporter number. J. Clin. Invest 83:199-204.

36. Ezaki, O. 1989. Mechanism for increased insulin stimulated glucose metabolism in adipocytes from 13 week-old obese Zucker rats. Diabetologia. 32:290-294.

37. Hainault, I., M. Guerre-Millo, C. Guichard, and M. Lavau. 1991. Differential regulation of adipose tissue glucose transporters in genetic obesity (fatty rat). Selective increase in the adipose cell/muscle glucose transporter (Glut 4) expression. J. Clin. Invest. 87:1127-1131.

38. Kahn, B. B., and J. S. Flier. 1990. Regulation of glucose transporter gene expression in vitro and in vivo. Diabetes Care. 13:548-564.

39. Ezaki, O., N. Fukuda, and H. Itakura. 1990. Role of two types of glucose transporters in enlarged adipocytes from aged obese rats. Diabetes. 39:15431549 .

40. Dugail, I., A. Quignard-Boulange, R. Bazin, X. Le Liepre, and M. Lavau. 1988. Adipose-tissue-specific increase in glyceraldehyde-3-phosphate dehydrogenase activity and mRNA amounts in suckling pre-obese Zucker rats. Effect of weaning. Biochem. J. 254:483-487. 